\title{
Effects of low-dose bufalin combined with hydroxycamptothecin on human castration-resistant prostate cancer xenografts in nude mice
}

\author{
RENZE GU and QINGCHUAN ZHANG \\ Department of Urology, Putuo Hospital, Shanghai University of Traditional Chinese Medicine, Shanghai 200062, P.R. China
}

Received December 7, 2018; Accepted December 11, 2019

DOI: $10.3892 /$ etm.2021.10447

\begin{abstract}
Prostate cancer is the most prevalent tumor found in men worldwide. Despite the efficiency of primary endocrine prostate cancer therapies, more efficient drugs are needed to tackle the most advanced and resistant forms of this condition. The present study investigated the antitumor effects of low-dose bufalin combined with hydroxycamptothecin on castration-resistant prostate cancer (CRPC) in mice, as well as the possible mechanisms of apoptosis induction. CRPC xenograft tumors were generated in mice and, subsequently, mice received appropriate doses of bufalin, hydroxycamptothecin or a combination of the two drugs. Tumors from each treatment group were removed, and the tumor volume, weight and inhibition rate of each group was determined. Hematoxylin and eosin staining was performed for pathological analysis and TUNEL staining was used to assess the level of apoptosis in the xenografts. Immunohistochemistry was used for the analysis of proliferating cell nuclear antigen expression and the expression of Bax, Bcl-XL, p53, programmed cell death 4 (PDCD4), phosphorylated (p)-AKT and glycogen synthase kinase (GSK)-3 $\beta$ was determined by western blotting. Treatment with bufalin significantly $(\mathrm{P}<0.05)$ reduced tumor volumes compared with the negative control group, reducing tumor volumes to lower levels when combined with hydroxycampothecin. The combination of bufalin $(0.6$ or $0.8 \mathrm{mg} / \mathrm{kg})$ and hydroxycampothecin significantly $(\mathrm{P}<0.05)$ induced higher levels of cell apoptosis compared with the administration of bufalin or hydroxycampothecin alone. The combination of bufalin and hydroxycampothecin also increased the expression
\end{abstract}

Correspondence to: Dr Qingchuan Zhang, Department of Urology, Putuo Hospital, Shanghai University of Traditional Chinese Medicine, 164 Lanxi Road, Shanghai 200062, P.R. China E-mail: zhangqingchuan1973@163.com

Abbreviations: CRPC, castration-resistant prostate cancer; FBS, fetal bovine serum; PCNA, proliferating cell nuclear antigen; PDCD4, programmed cell death 4

Key words: castration-resistant prostate cancer, bufalin, hydroxycamptothecin, drug combination of apoptosis-related proteins Bax, p53, PDCD4 and GSK-3 $\beta$, and decreased the expression of Bcl-XL and p-AKT compared with a single drug treatment. The present study suggested that the combination of bufalin and hydroxycampothecin improved the inhibitory effects of both drugs on CRPC tumors in vivo, potentially via the regulation of the PI3K/AKT/GSK-3 $\beta$ and p53-dependent apoptosis signaling pathways.

\section{Introduction}

Prostate cancer is a high-risk malignant tumor of the urinary tract, typically diagnosed in middle-aged and elderly men (1). The worldwide incidence rate of prostate cancer accounted for $15 \%$ of the total number of malignant tumors in males in 2012 (2), displaying a significant upward trend each year (3). Prostate cancer is the third largest cause of cancer-associated death in males in the United States (4) and the second largest cause worldwide (2). At present, the treatment of prostate cancer includes surgery, radiotherapy, chemotherapy and endocrine therapy (5). However, for advanced prostate cancer, surgery is ineffective and other treatment options are not satisfactory, with the majority being associated with severe adverse reactions (5). The main therapeutic strategy for prostate cancer is endocrine therapy, however, after a median of 18-20 months, the majority of patients will eventually develop androgen resistance, with a median survival of 12 months $(6,7)$. Therefore, the treatment of castration-resistant prostate cancer (CRPC) has become a focus in urology research and the identification of novel treatment options is required (8).

Bufalin is a steroidal terpene compound, and is one of the active ingredients in traditional Chinese medicine (9). Bufalin has been reported to be useful in the treatment of liver and pancreatic cancers, as well as other tumors (9-12). Previous studies have reported that bufalin can significantly inhibit the proliferation of PC3 CRPC cells in vitro $(13,14)$. However, the therapeutic dose is close to the toxic dose, which limits its clinical application $(15,16)$. Bufalin is a DNA topoisomerase (TOP)II inhibitor (17), and its mechanism of action is related to the inhibition of tumor proliferation, metastasis and angiogenesis, as well as the reversal of tumor resistance (18-21). Cortés and Piñero (22) reported that DNA TOPI inhibition in ovarian cells by the TOPI inhibitor irinotecan resulted in increased levels of TOPII mRNA and protein expression, allowing DNA metabolism to continue $(23,24)$. This phenomenon is called the 
side-channel sensitivity of TOP, and is required to maintain the normal physiological state of the cells $(25,26)$. In oral cancer research, Ding et al (27) combined the TOPI inhibitor irinotecan and the TOPII inhibitor doxorubicin to improve treatment efficacy.

Previous studies have reported that the DNA TOPI inhibitor hydroxycamptothecin and the TOPII inhibitor bufalin can inhibit the growth of the CRPC cell line DU 145 in vitro $(28,29)$. These studies also suggested that simultaneous administration of the two inhibitors was not as effective as individual drug administration, due to antagonism, but sequential administration significantly improved the results obtained $(28,29)$.

The present study investigated whether bufalin in combination with hydroxycamptotecin would exhibit the same effect in vivo, as has been reported in previous in vitro studies. Furthermore, the present study aimed to identify a dose of low-toxicity bufalin combined with hydroxycamptothecin for further clinical applications.

\section{Materials and methods}

Cell lines and cell culture. The human prostate cancer cell line DU 145, purchased from Thermo Fisher Scientific, Inc., was cultured in RPMI 1640 complete medium (Sigma-Aldrich; Merck KGaA) containing 10\% fetal bovine serum (FBS; Sigma-Aldrich; Merck KGaA) and $1 \%$ penicillin and streptomycin solution, at $37^{\circ} \mathrm{C}$ with $5 \% \mathrm{CO}_{2}$ and fully saturated humidity. Cells were subcultured each for 2-3 days.

Establishment of a CRPC xenograft model in nude mice and treatment administration. A total of 41 male BALB/c nude mice (age, 22-25 g; 6-8 weeks), obtained from the Experimental Animal Center of Shanghai University of Traditional Chinese Medicine were housed under pathogen-free condition at $22 \pm 2^{\circ} \mathrm{C}$ with $40-60 \%$ humidity, 12 -h light/dark cycles and free access to food and water. Cell suspensions of DU 145 cells in the logarithmic growth phase were prepared at a concentration of $1 \times 10^{7}$ cells $/ \mathrm{ml}$, using physiological saline. To induce tumor formation, five mice were subcutaneously injected in the abdomen with $0.2 \mathrm{ml}$ cell suspension. At three weeks post-inoculation, when the diameters of the primary implanted tumors had grown to $1 \mathrm{~cm}^{3}$, tumors were removed and abdominally implanted into the other 36 mice. After 8 days, drugs were administered once every other day for 30 days. For drug administration, the 36 tumor-bearing mice were randomly divided into six groups, with six mice in each group. The groups were as follows: Normal saline negative control group (SN), hydroxycamptothecin (2 mg/kg; BioCrick) single drug positive control group $(\mathrm{H})$, bufalin $(1 \mathrm{mg} / \mathrm{kg}$, Sigma-Aldrich; Merck KGaA) single drug positive control group (B) and hydroxycamptothecin $(2 \mathrm{mg} / \mathrm{kg})$ sequentially combined with $0.4 \mathrm{mg} / \mathrm{kg}$ bufalin treatment group (H4B), $0.6 \mathrm{mg} / \mathrm{kg}$ bufalin treatment group $(\mathrm{H} 6 \mathrm{~B})$ or $0.8 \mathrm{mg} / \mathrm{kg}$ bufalin treatment group (H8B). No adverse reactions were reported in the mice in the combined treatment groups. The sequential co-administration method involved administration of the corresponding dose of bufalin $8 \mathrm{~h}$ after the administration of hydroxycamptothecin, as previously described (30). The present study was approved by the Institutional Ethics Committee of Shanghai University of Traditional Chinese Medicine.
Morphological and histological observation of tumors. A total of one day post-treatment, the six mice in each group were sacrificed and the tumors were completely removed. The tumors from each group were compared by morphological analysis. The long diameter (a) and short diameter (b) of the tumor were measured. Tumor parameters were calculated using the following formulae: Tumor volume $\left(\mathrm{V} ; \mathrm{mm}^{3}\right)=\left(\mathrm{ab}^{2}\right) / 2$; tumor-inhibition rate $(\%)=[1-(\mathrm{V}$ administration group $/ \mathrm{V}$ negative control group)] x100; and tumor mass was determined using an electronic balance. A section of the tumor mass was removed, fixed in $10 \%$ formalin $(\mathrm{pH} \mathrm{7.4)}$ ) at room temperature for $24 \mathrm{~h}$ and embedded in paraffin. The paraffin-embedded samples were sectioned $(4 \mu \mathrm{m})$. For pathological analysis, sections were stained at room temperature using haemotoxylin for $3 \mathrm{~min}$ and eosin for $30 \mathrm{sec}$ (HE). Subsequently, tissue sections were examined using the Leica DM6 B light microscope (Leica Microsystems Inc.; magnification, x4, x10 and $\mathrm{x} 40)$.

TUNEL detection. The TUNEL Assay kit-FITC (cat. no. ab66108; Abcam) was used to detect apoptosis in paraffin-embedded sections, according to the manufacturer's protocol. The staining of tumor cells in each group was observed under a fluorescence microscope (Leica DMLB; Leica Microsystems Inc.; magnification, x400) and necrotic areas were avoided. TUNEL-positive cells were observed in five randomly-selected high-power fields. The integrated optical density (IOD) values of the images were analyzed using Image-Pro Plus software (version 6.0; Media Cybernetics, Inc.) to assess the extent of apoptosis in tumor cells.

Detection of proliferating cell nuclear antigen (PCNA) protein expression by immunohistochemistry. Immunohistochemical staining was performed to detect the expression of PCNA in the xenograft tumors. Paraffin sections were rehydrated. The sections were subsequently treated as follows: Microwave antigen retrieval $(700 \mathrm{~W}$ for $8 \mathrm{~min}$; twice in $10 \mathrm{mM}$ sodium citrate; $\mathrm{pH}$ 6.0) was followed by incubation with $3 \%$ hydrogen peroxide to block endogenous peroxidase and $10 \%$ goat serum (cat. no. 5560-0007; Seracare Life Sciences, Inc.) at $4^{\circ} \mathrm{C}$ for 30 min to block nonspecific binding. PCNA was detected with rabbit anti-PCNA (1:100; cat. no. ab18197; Abcam) overnight at $4^{\circ} \mathrm{C}$ and horseradish peroxidase-conjugated goat anti-rabbit immunoglobulin G secondary antibody (1:400; cat. no. ab205718; Abcam) for $1 \mathrm{~h}$ at room temperature. After that, 3,3-diaminobenzidine tetrahydrochloride (DAB; cat. no. 30015; Biotium, Inc.) was used for the chromomeric reaction, and hematoxylin was used to stain the nucleus for $5 \mathrm{~min}$ at room temperature. The staining of the tumor nuclei in each group was observed using a Leica DFC300 FX light microscope (Leica Microsystems Inc.; IL; magnification, $\mathrm{x} 400$ ). PCNA-positive cells, displaying brown-yellow granules in the nuclei, were observed in five randomly-selected high-power fields. The integrated optical density (IOD) values of the images were analyzed using Image-Pro Plus software (version 6.0; Media Cybernetics, Inc.). For the negative control, the primary antibody was replaced by normal rabbit IgG.

Western blotting. A homogenizer was used to prepare lysates from xenograft tumor tissues. The xenograft tumor tissues 
were lysed in radioimmunoprecipitation assay lysis buffer (Rockland Immunochemicals, Inc.) according to the standard protocol. Total protein was quantified using a bicinchoninic acid assay. Total protein lysate $(50 \mu \mathrm{g})$ was loaded into each lane and separated using 12\% SDS-PAGE gels. The separated proteins were then transferred onto PVDF membranes (Merck KGaA) and 3\% BSA (cat. no. PRO-22; ProSpec-Tany TechnoGene, Ltd.) in TBS-Tween-20 (TBST) was added to the membranes for $1 \mathrm{~h}$ at room temperature. The membranes were washed three times with TBST and were subsequently incubated with diluted primary antibodies overnight. Primary antibodies including Bax (1:1,000; cat. no. 2772), Bcl-XL (1:1,000; cat. no. 2764), p53 (1:1,000; cat. no. 2527), PDCD4 (1:1,000; cat. no. 9535), GSK-3ß (1:1,000; cat. no. 12456), p-AKT (1:2,000; cat. no. 4060), AKT (1:1,000; cat. no. 4685) and GAPDH (1:1,000; cat. no. 5174) were added and incubated overnight at $4^{\circ} \mathrm{C}$. Following the primary incubation, membranes were washed with TBST three times ( $\mathrm{x} 5 \mathrm{~min}$ ) and then incubated with the horseradish peroxidase-conjugated goat anti-rabbit immunoglobulin $\mathrm{G}$ secondary antibody $(1: 1,000$; cat. no. 4030-05; SouthernBiotech) for $1 \mathrm{~h}$ at room temperature. After washing the membranes three times with TBST, Immunoblot detection and visualization were performed using enhanced chemiluminescence western blotting detection reagents (SuperSignal ${ }^{\mathrm{TM}}$ West Pico PLUS Chemiluminescent Substrate; cat. no. 34577; Thermo Fisher Scientific, Inc.). Immunoblotting was performed with target antibodies and protein bands were scanned and quantified using a ChemiDoc image analysis system (Bio-Rad Laboratories, Inc.). ImageJ software (version 1.46; Natioanl Institutes of Health) was used for densitometry analysis. All Primary antibodies were purchased from the Cell Signaling Technology, Inc.

Data analysis and statistical processing. Statistical analysis was performed using SPSS software (version 21.0; IBM Corp.). Data are presented as the mean \pm standard deviation. All experiments were performed in triplicate. Data were analyzed by one-way ANOVA followed by Bonferroni post-hoc test. The Wilcoxon rank sum test was used to compare non-normally distributed data sets in non-parametric tests. The Mann-Whitney U method was used to test the significant differences between groups. $\mathrm{P}<0.05$ was considered to indicate a statistically significant difference.

\section{Results}

Comparison of tumor size in different groups. After successful establishment of CRPC xenografts in mice, the mice were weighed and no statistically significant difference was observed between treatment groups (Table I; P>0.05). The mice in the treatment groups displayed no abnormal changes in body weight or behavior. The mice were sacrificed one day post-treatment and comparisons of tumor size of the xenograft tumors isolated from different groups were performed (Fig. 1A).

The volume and weight of the xenograft tumors were measured. All drug treatments significantly reduced the tumor volume compared with the $\mathrm{SN}$ group $(\mathrm{P}<0.05$; Fig. $1 \mathrm{~B})$. Among the different drug treatment groups, the H6B and $\mathrm{H} 8 \mathrm{~B}$ groups were more effective at inhibiting increases in the tumor volume compared with the single drug administration groups ( $\mathrm{H}$ or $\mathrm{B}$ ) and the $\mathrm{H} 4 \mathrm{~B}$ group $(\mathrm{P}<0.05$; Table I; Fig. 1B). However, the H6B group displayed the lowest tumor volume out of all of the groups (Table I; Fig. 1B). Similarly, in terms of tumor weight, the H6B and H8B groups were more effective at inhibiting tumor growth compared with all other groups $(\mathrm{P}<0.05$; Table I; Fig. 1C). The tumor weight of the H4B and $\mathrm{H}$ groups was significantly reduced compared with the $\mathrm{SN}$ group $(\mathrm{P}<0.05$; Table I; Fig. 1C). However, the $\mathrm{B}$ group did not display a significant difference in tumor weight compared with the SN group ( $\mathrm{P}>0.05$; Table I; Fig. 1C). Additionally, although the H6B group appeared to limit tumor weight to a further extent than the H8B group, the difference was not significant (P>0.05; Table I; Fig. 1C).

The tumor-inhibition rate of each group was calculated in each treatment group. The tumor-inhibition rate of the $\mathrm{H} 6 \mathrm{~B}$ and $\mathrm{H} 8 \mathrm{~B}$ groups was $>80 \%$, which was significantly higher than that of the single drug administration groups $(\mathrm{P}<0.05$; Fig. 1D). The tumor-inhibition rate in the H6B group reached $92.99 \pm 3.96 \%$, but there was no statistical difference between the H6B and H8B groups (P>0.05; Table I; Fig. 1D). The tumor-inhibition rate in the H4B group was not significantly different $(\mathrm{P}>0.05)$ from that in the $\mathrm{H}$ group, but was significantly $(\mathrm{P}<0.05)$ improved compared with the B group (Fig. 1D).

Pathological observation by HE staining. HE staining was performed on the xenograft tumors and suggested that the normal tissue structure was disorganized in each group, as indicated by disorderly cell distribution and different cell sizes. The nuclei morphology was irregular and several nuclei were much larger in the treatment groups compared with the SN group. In addition, the nucleus to cytoplasmic ratio was increased in the treatment groups compared with the SN group. In the drug-administered groups, obvious cavities were identified in the central part of the tumor cells and the cell size was different compared with the SN group. Furthermore, the drug-administered groups displayed no structural eosinophilic red staining or nuclear debris. The number of tumor cells in the cavity of drug-administered groups was reduced compared with the SN group, and it was impossible to distinguish apoptosis and necrosis. In the $\mathrm{H}, \mathrm{B}$ and $\mathrm{H} 4 \mathrm{~B}$ groups, small changes to the structure and an interstitial connection in the cavity were observed, while in the H6B and H8B groups, severe cavity changes were observed and the original tissue structures could not be seen under the microscope. Therefore, it was speculated that the tumor suppressing effect of the two drugs was stronger in the combination therapy groups compared with the monotherapy groups (Fig. 2).

TUNEL assay for apoptosis. The TUNEL kit was used to detect apoptosis in the xenograft tumors of each group. The drug-administered groups displayed significantly higher levels of apoptosis compared with the SN group $(\mathrm{P}<0.05$; Fig. 3A and B). Among the drug-administered groups, the H6B group displayed the highest level of apoptosis. The H8B group did not induce apoptosis to the same extent as the H6B group, but still displayed significantly $(\mathrm{P}<0.05)$ higher levels of apoptosis compared with the single drug administration groups $(\mathrm{H}$ and $\mathrm{B})$ and the H4B group. No statistically significant $(\mathrm{P}>0.05)$ 
Table I. Comparison of the weight of nude mice, as well as the volume, weight and inhibition rate of the xenograft tumors.

\begin{tabular}{lccccc}
\hline Group & $\mathrm{n}$ & Tumor volume $\left(\mathrm{mm}^{3}\right)$ & Tumor weight $(\mathrm{g})$ & Tumor-inhibition rate $(\%)$ & Nude mice weight $(\mathrm{g})$ \\
\hline SN & 6 & $543.55 \pm 121.51$ & $0.29 \pm 0.08$ & & $21.82 \pm 0.84$ \\
H & 6 & $214.76 \pm 115.54$ & $0.17 \pm 0.07$ & $58.47 \pm 19.65$ & $23.25 \pm 2.28$ \\
B & 6 & $378.86 \pm 115.39$ & $0.30 \pm 0.08$ & $29.72 \pm 19.04$ & $21.38 \pm 1.54$ \\
H4B & 6 & $175.42 \pm 83.06$ & $0.12 \pm 0.05$ & $70.10 \pm 14.85$ & $22.70 \pm 2.57$ \\
H6B & 6 & $34.76 \pm 22.26$ & $0.03 \pm 0.02$ & $92.99 \pm 3.96$ & $22.32 \pm 2.65$ \\
H8B & 6 & $101.93 \pm 55.82$ & $0.08 \pm 0.04$ & $81.26 \pm 9.19$ & $23.50 \pm 2.06$ \\
\hline
\end{tabular}

$\mathrm{SN}$, saline negative control group; $\mathrm{H}$, hydroxycamptothecin positive control group; B, bufalin positive control group; H4B, combination of hydroxycampothecin and $0.4 \mathrm{mg} / \mathrm{kg}$ bufalin; H6B, combination of hydroxycampothecin and $0.6 \mathrm{mg} / \mathrm{kg}$ bufalin; H8B, combination of hydroxycampothecin and $0.8 \mathrm{mg} / \mathrm{kg}$ bufalin.

A



C

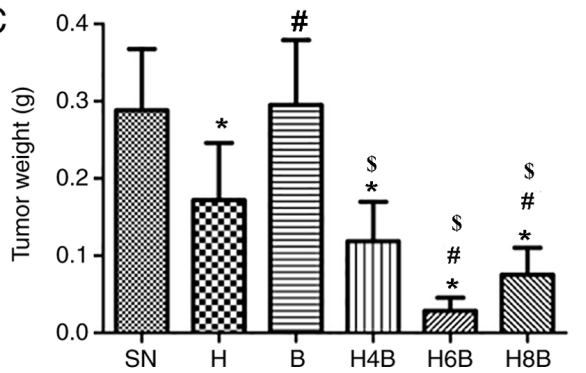

B

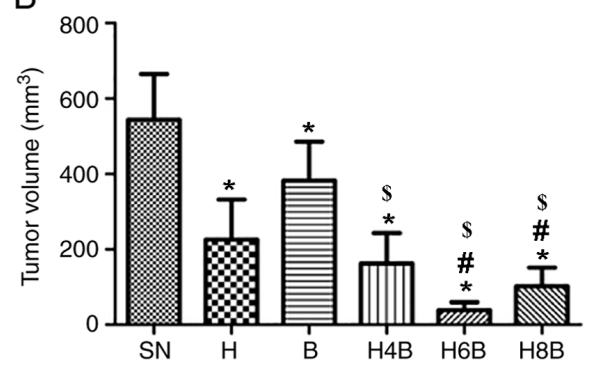

$\mathrm{D}$

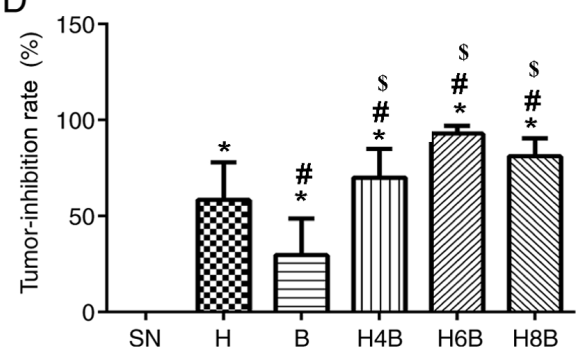

Figure 1. Morphological comparison of tumors. (A) Image of isolated xenograft tumors from each group. The tumor (B) volume, (C) weight and (D) inhibition rate of prostate cancer xenograft tumors in nude mice in each group. Data are presented as the mean $\pm \mathrm{SD}\left(\mathrm{n}=6\right.$ per group). ${ }^{*} \mathrm{P}<0.05 \mathrm{vs}$. the $\mathrm{SN}$ group; ${ }^{\circledR} \mathrm{P}<0.05$ vs. the $\mathrm{H}$ group and ${ }^{~} \mathrm{P}<0.05$ vs. the $\mathrm{B}$ group. $\mathrm{SN}$, saline negative control group; $\mathrm{H}$, hydroxycamptothecin positive control group; $\mathrm{B}$, bufalin positive control group; H4B, combination of hydroxycampothecin and $0.4 \mathrm{mg} / \mathrm{kg}$ bufalin; H6B, combination of hydroxycampothecin and $0.6 \mathrm{mg} / \mathrm{kg}$ bufalin; H8B, combination of hydroxycampothecin and $0.8 \mathrm{mg} / \mathrm{kg}$ bufalin.

differences were found between the H4B group and the single drug administration groups (Fig. 3A and B).

Differential expression of PCNA protein. The PCNA protein is ubiquitously expressed in the nucleus, and its nuclear content is consistent with the synthesis of DNA, making PCNA an indicator of cell proliferation (31). The expression of PCNA in prostate cancer xenograft tumors was analyzed by immunohistochemistry. PCNA-positive cells were stained brown or yellow, indicating that the cells were proliferating and dividing (Fig. 4A).

The xenograft tumors of the drug-administered groups displayed significantly reduced PCNA levels compared with the $\mathrm{SN}$ group $(\mathrm{P}<0.05$; Fig. $4 \mathrm{~A}$ and $\mathrm{B})$. The H6B and H8B groups displayed the lowest levels of PCNA expression compared with all the other treatment groups $(\mathrm{P}<0.05$; Fig. $4 \mathrm{~A}$ and $\mathrm{B})$. There was no significant difference $(\mathrm{P}>0.05)$ between the PCNA expression in xenograft tumors from the H4B group and the single drug administration groups ( $\mathrm{H}$ and $\mathrm{B})$. The H6B group exhibited the most significant effect on PCNA expression, and there was a statistical difference compared with the single drug administration groups $(\mathrm{P}<0.05$; Fig. 4B).

Expression of apoptosis-related proteins Bax, p53, programmed cell death 4 (PDCD4) and glycogen synthase kinase $(G S K)-3 \beta$. To further explore the mechanisms of drug inhibition on tumor growth, the expression of cytoplasmic proteins in xenograft tumors was determined by western blotting. All drug treatments increased the protein expression levels of the tumor suppressor genes p53 and PDCD4, the mitochondrial apoptosis-related protein Bax and the PI3K/AKT/GSK-3 $\beta$ apoptosis signaling pathway-related protein GSK-3 $\beta$, compared 
SN
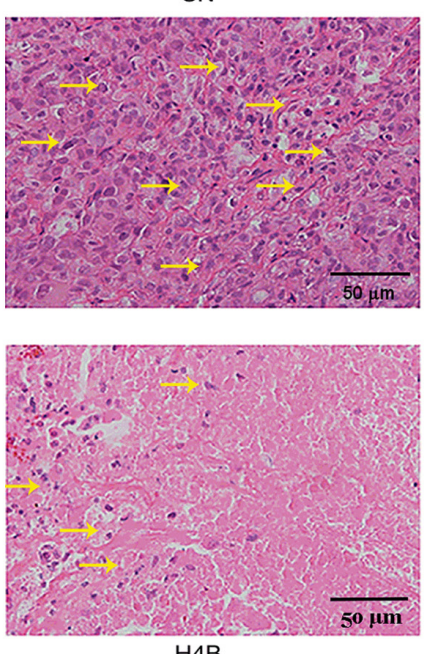

$\mathrm{H} 4 \mathrm{~B}$
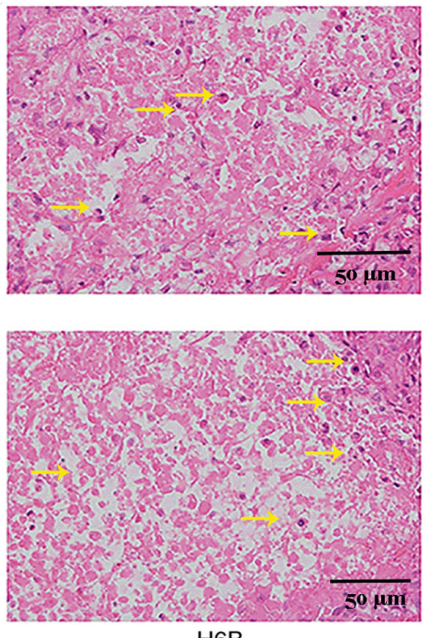

$\mathrm{H} 6 \mathrm{~B}$
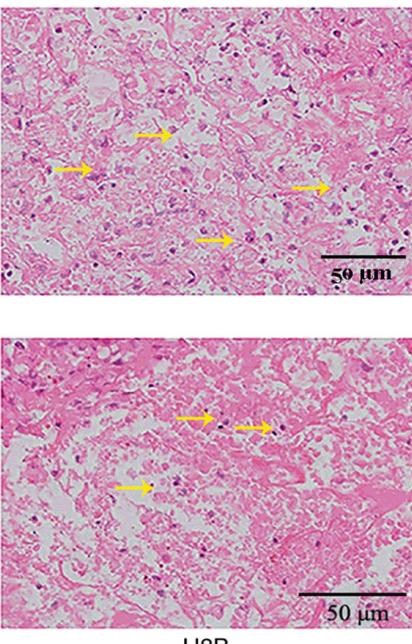

$\mathrm{H} 8 \mathrm{~B}$

Figure 2. Pathological assessment by HE staining. HE staining of prostate cancer xenograft tumors in nude mice in each group. Yellow arrows: Tumor cells $\mathrm{SN}$, saline negative control group; $\mathrm{H}$, hydroxycamptothecin positive control group; $\mathrm{B}$, bufalin positive control group; H4B, combination of hydroxycampothecin and $0.4 \mathrm{mg} / \mathrm{kg}$ bufalin; H6B, combination of hydroxycampothecin and $0.6 \mathrm{mg} / \mathrm{kg}$ bufalin; H8B, combination of hydroxycampothecin and $0.8 \mathrm{mg} / \mathrm{kg}$ bufalin.

B
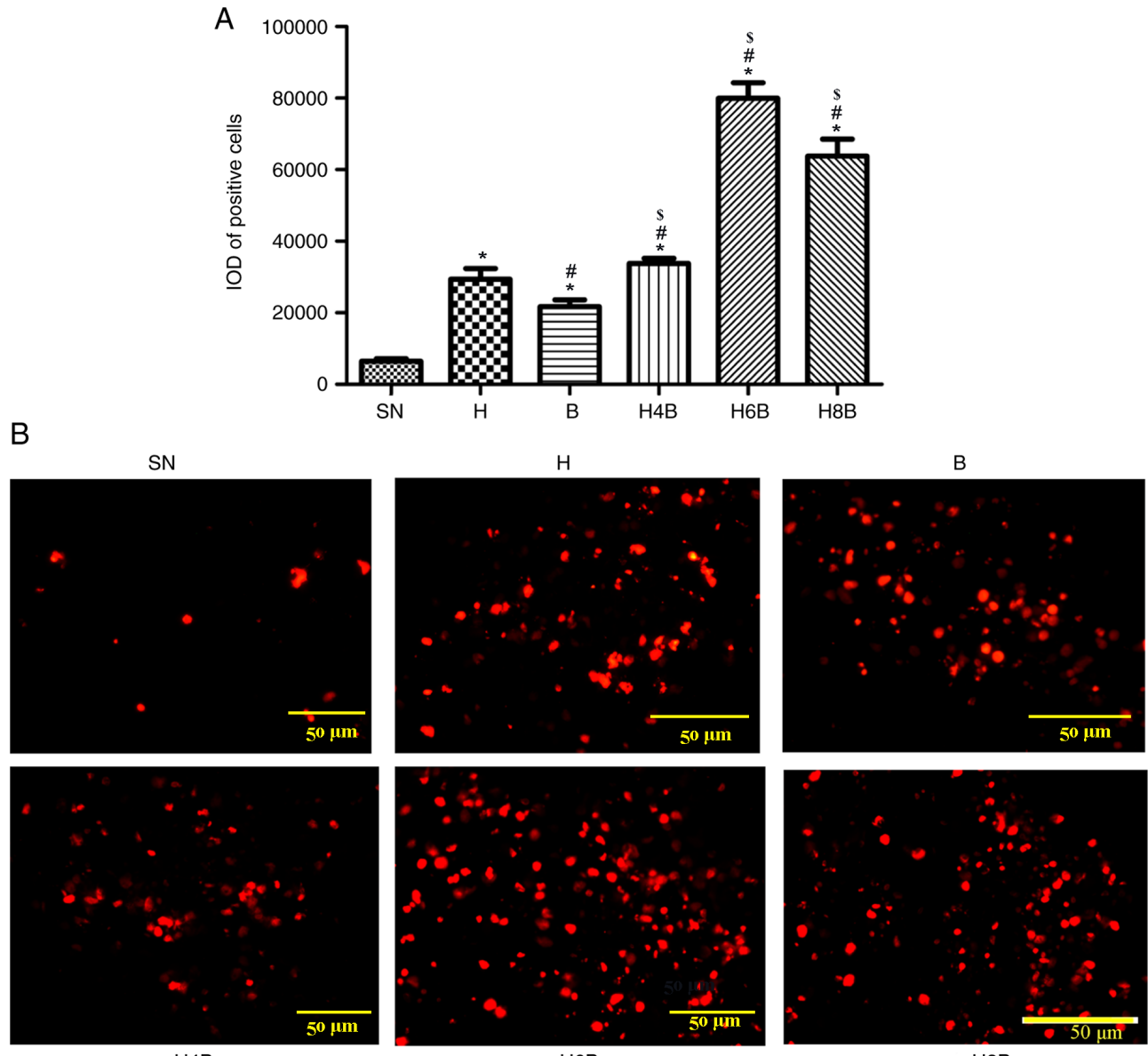

H4B

H6B

H8B

Figure 3. TUNEL assay for apoptosis. (A) The sum of the IOD values of TUNEL fluorescence for apoptosis-positive cells in prostate cancer xenograft tumors of nude mice in each group. (B) TUNEL fluorescence for apoptosis detection in prostate cancer xenograft tumors in nude mice in each group. Data are presented as the mean $\pm \mathrm{SD}$ ( $\mathrm{n}=6$ per group). ${ }^{*} \mathrm{P}<0.05$ vs. the $\mathrm{SN}$ group; ${ }^{\$} \mathrm{P}<0.05$ vs. the $\mathrm{H}$ group; ${ }^{\#} \mathrm{P}<0.05 \mathrm{vs}$. the B group. IOD, integrated optical density; $\mathrm{SN}$, saline negative control group; $\mathrm{H}$, hydroxycamptothecin positive control group; B, bufalin positive control group; H4B, combination of hydroxycampothecin and $0.4 \mathrm{mg} / \mathrm{kg}$ bufalin; H6B, combination of hydroxycampothecin and $0.6 \mathrm{mg} / \mathrm{kg}$ bufalin; H8B, combination of hydroxycampothecin and $0.8 \mathrm{mg} / \mathrm{kg}$ bufalin.

with the SN group (Fig. 5). Furthermore, all drug treatments decreased the protein expression levels of the mitochondrial apoptosis-related protein Bcl-XL and the PI3K/AKT/GSK-3 $\beta$ apoptosis signaling pathway-related protein $\mathrm{p}-\mathrm{AKT}$, compared 
A
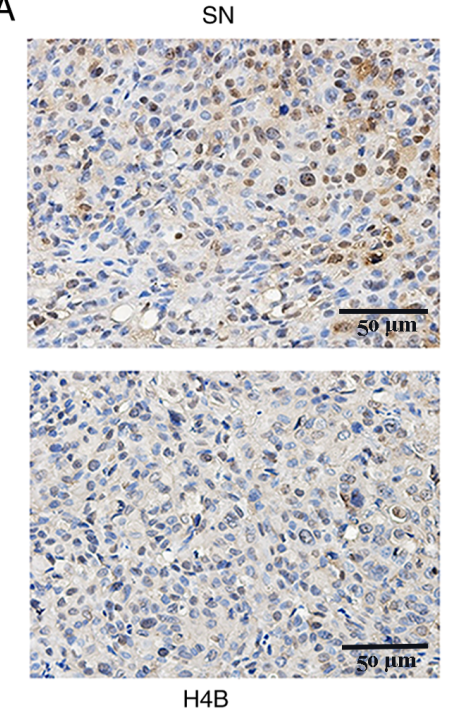

$\mathrm{H}$
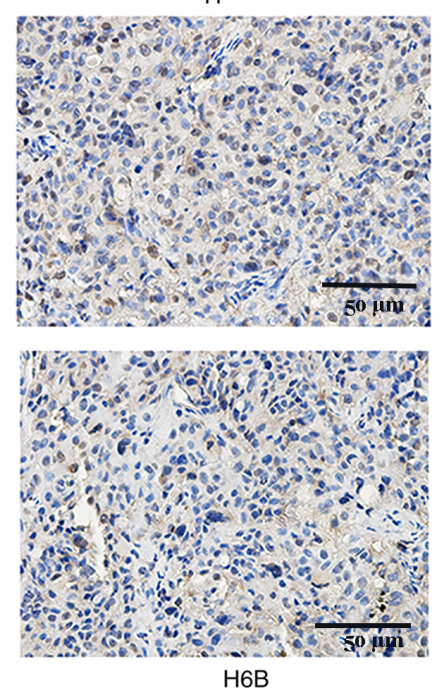

B
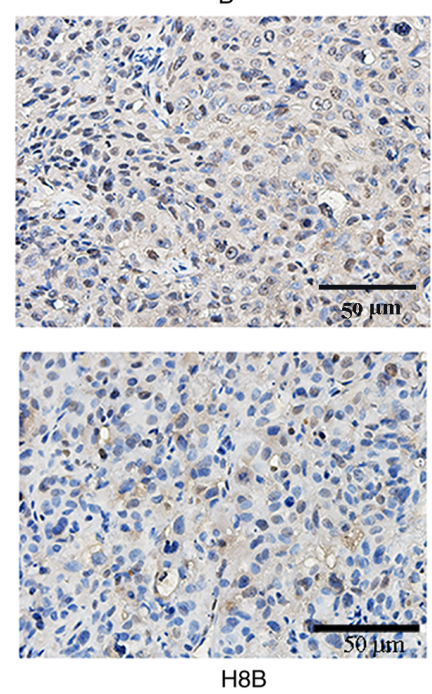

B

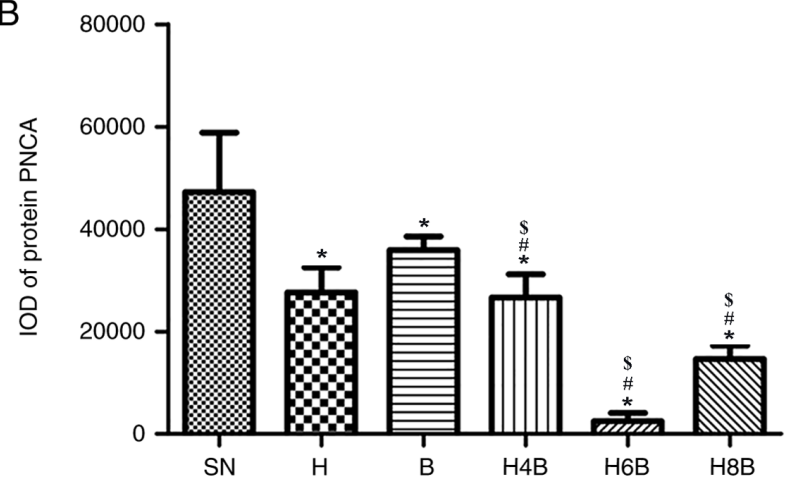

Figure 4. Differential expression of the PCNA protein. (A) PCNA protein expression in prostate cancer xenograft tumors in nude mice in each group was detected using immunohistochemistry. (B) PCNA protein expression in prostate cancer xenograft tumors of nude mice in each group. Data are presented as the mean $\pm \mathrm{SD}$ ( $\mathrm{n}=6$ per group). ${ }^{*} \mathrm{P}<0.05$ vs. the $\mathrm{SN}$ group; ${ }^{\$} \mathrm{P}<0.05$ vs. the $\mathrm{H}$ group; ${ }^{\prime} \mathrm{P}<0.05$ vs. the $\mathrm{B}$ group. IOD, integrated optical density; SN, saline negative control group; $\mathrm{H}$, hydroxycamptothecin positive control group; $\mathrm{B}$, bufalin positive control group; H4B, combination of hydroxycampothecin and $0.4 \mathrm{mg} / \mathrm{kg}$ bufalin; H6B, combination of hydroxycampothecin and $0.6 \mathrm{mg} / \mathrm{kg}$ bufalin; H8B, combination of hydroxycampothecin and $0.8 \mathrm{mg} / \mathrm{kg}$ bufalin.

with the SN group (Fig. 5). Additionally, the H4B, H6B and H8B groups significantly increased the protein expression levels of Bax, p53, PDCD4 and GSK-3 $\beta$, and decreased the protein expression levels of Bcl-XL and p-AKT compared with the single drug administration groups $(\mathrm{H}$ and $\mathrm{B} ; \mathrm{P}<0.05$; Fig. 5). Among the combination treatment groups, the changes were the most prominent in the H6B group, followed by the H8B and H4B treatment groups, respectively, although there was no significant difference among the three groups.

\section{Discussion}

The use of bufalin for the inhibition of tumor cell growth has been researched extensively in precious years (32-37). Low-dose bufalin displays an inhibitory effect on the growth of prostate cancer DU 145 cells in a time and dose-dependent manner (38). Administration of a combination of a specific dose of hydroxycamptothecin with a single agent was found to be effective against cancer cells (28). Similar synergy was also reported for the combination of hydroxycamptothecin and etoposide in human colon carcinoma HT-29 cells (39).

The present study suggested that in a nude mouse CRPC xenograft model, low-dose bufalin inhibited increases in tumor volume and weight, but bufalin ( 0.6 and $0.8 \mathrm{mg} / \mathrm{kg}$ ) combined with hydroxycamptothecin had an improved effect on tumor volume, weight and inhibition rate compared with the administration of either drug alone. Histopathological analysis of sections of the xenograft tumors indicated increased cell death with the combined administration of bufalin and hydroxycamptothecin compared with the other groups. The TUNEL assay suggested that the H6B and H8B groups promoted higher levels of tumor cell apoptosis compared with the single drug administration groups. Immunohistochemical staining indicated that the H6B and $\mathrm{H} 8 \mathrm{~B}$ groups were more effective at inhibiting the proliferation of prostate cancer cells than all other treatment groups. The proapoptotic and growth-inhibiting effects of bufalin, hydroxycamptothecin or their combination may be related to the mitochondrial, p53-related and PI3K/AKT/GSK-3 $\beta$ apoptotic signaling pathways.

In recent years, bufalin has been reported to exhibit proapoptotic effects in a number of tumors $(40-44,41)$, but the effective dose $(\geq 1.5 \mathrm{mg} / \mathrm{kg})$ utilized in previous studies is close to the toxic dose. According to the Dictionary of Traditional Chinese Medicine, the median lethal dose $\left(\mathrm{LD}_{50}\right)$ of bufalin in nude mice is $2.2 \mathrm{mg} / \mathrm{kg}$ (45), and a number of previous studies have reported that $1.5 \mathrm{mg} / \mathrm{kg}$ bufalin significantly promoted the 



Figure 5. Expression of apoptosis-related proteins. The expression of apoptosis-related proteins, Bax, p53, PDCD4, Bcl-XL, p-AKT and GSK-3 $\beta$ in prostate cancer xenograft tumors of nude mice in each group. Data are presented as the mean $\pm \mathrm{SD}\left(\mathrm{n}=6\right.$ per group). ${ }^{*} \mathrm{P}<0.05$ vs. the $\mathrm{SN}$ group; ${ }^{\mathrm{S}} \mathrm{P}<0.05$ vs. the $\mathrm{H}$ group

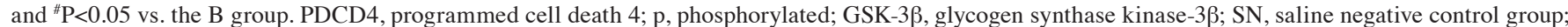
$\mathrm{H}$, hydroxycamptothecin positive control group; B, bufalin positive control group; H4B, combination of hydroxycampothecin and $0.4 \mathrm{mg} / \mathrm{kg}$ bufalin; $\mathrm{H} 6 \mathrm{~B}$, combination of hydroxycampothecin and $0.6 \mathrm{mg} / \mathrm{kg}$ bufalin; H8B, combination of hydroxycampothecin and $0.8 \mathrm{mg} / \mathrm{kg}$ bufalin.

apoptosis of transplanted tumor cells and exhibited antitumor effects in nude mice $(37,46,16,37)$. In the present study, the dose of bufalin used in the combination treatment groups ( 0.4 , 0.6 and $0.8 \mathrm{mg} / \mathrm{kg}$ ) was much lower than the $\mathrm{LD}_{50}$ value. There was no significant difference in the body weight of mice in the treatment groups compared with the SN group. The effects of the three combined treatment groups were no less than those of the bufalin $(1.0 \mathrm{mg} / \mathrm{kg})$ alone positive control group. Therefore, it can be suggested that the use of low-dose bufalin combined with hydroxycamptothecin may have a significant therapeutic effect, and may not be associated with toxicity, providing rationale for the clinical use of low-dose bufalin. However, the administration of a bufalin and hydroxycamptothecin combination would need to follow a specific protocol. The present study further suggested that the simultaneous administration of bufalin and hydroxycamptothecin was effective in the treatment of CRPC. The use of bufalin and hydroxycamptothecin simultaneously leads to drug antagonism, but sequential administration may lead to a synergistic effect (47). Therefore, administration of hydroxycamptothecin for a certain period of time prior to the administration of bufalin may be more effective (47). The present study suggested that the sequential administration of bufalin $(0.6$ and $0.8 \mathrm{mg} / \mathrm{kg}) 8 \mathrm{~h}$ after the administration of hydroxycamptothecin $(2 \mathrm{mg} / \mathrm{kg})$ was more beneficial. However, the role of hydroxycamptothecin in CRPC requires further investigation.

$\mathrm{Bcl}-\mathrm{XL}$ and Bax belong to the Bcl-2 protein family (48). By controlling the permeability of the mitochondrial inner membrane structure, Bcl-XL and Bax affect proapoptotic factors in the cytoplasm, including cytochrome $\mathrm{C}$, and transmit apoptotic signals to regulate cell death (49). Bax is an important component of mitochondrial membrane ion channels (50). After receiving the apoptotic signal, Bax expression is increased, proapoptotic factors in the mitochondria, such as cytochrome $\mathrm{C}$, enter the cytoplasm and the caspase protein family is activated to induce apoptosis (51-53). Bcl-XL is primarily located in the cytoplasm and can be translocated to the mitochondrial outer membrane to bind Bax and form Bcl-XL/Bax heterodimers, under the action of apoptotic signals $(20,21)$. Subsequently, the Bcl-XL/Bax heterodimers maintain the integrity of the mitochondrial outer membrane and interfere with apoptosis induction $(54,55)$. The sequential administration of bufalin $8 \mathrm{~h}$ after the administration of hydroxycamptothecin enhanced the expression of Bax and inhibited the expression of Bcl-XL, potentially promoting apoptosis. The present study suggested that the combination of hydroxycamptothecin and bufalin, at the dose of $0.6 \mathrm{mg} / \mathrm{kg}$, was the most beneficial treatment option.

Both p53 and PDCD4 are tumor suppressor genes, which play roles in cell apoptosis and DNA damage repair $(56,57)$. Under physiological conditions, p53 levels are low in the cell (58). When DNA damage occurs in cells, p53 accumulates in the cells and promotes the apoptosis of abnormal cells via the p53/Bax apoptosis regulatory signaling pathway to prevent excessive proliferation of abnormal cells $(59,60)$. The present study suggested that the apoptotic effect of bufalin on tumor cells is related to the activation of p53 and an increase in PDCD4 expression, which could potentially prevent the excessive proliferation of prostate cancer cells.

The PI3K/AKT signaling pathway is important for cell membrane receptor signaling (61). AKT regulates the 
proliferation of downstream proteins, including caspase 9, Bad, NF- $\mathrm{BB}$ and GSK-23, by phosphorylation, thereby regulating cell proliferation, differentiation, apoptosis and migration (62). GSK-3 $\beta$ can inhibit the expression of transcription factors, including $\beta$-catenin, Nrf2 and NFAT and activate the caspase pathway to induce apoptosis (63). The combination of bufalin and hydroxycamptothecin promoted the expression of GSK-3 $\beta$ and inhibited the expression of p-AKT, potentially inhibiting the growth of tumor cells. Furthermore, the combination of hydroxycamptothecin and bufalin at a dose of $0.6 \mathrm{mg} / \mathrm{kg}$ was the most effective at promoting GSK-3 $\beta$ expression and inhibiting p-AKT expression.

To conclude, sequential administration of bufalin and hydroxycamptothecin inhibited the growth of CRPC xenograft tumors. The dosage used for co-administration influenced the degree of drug inhibition. The administration of hydroxycamptothecin $(2 \mathrm{mg} / \mathrm{kg})$ followed by the administration of bufalin $(0.6 \mathrm{mg} / \mathrm{kg}) 8 \mathrm{~h}$ later was the most effective treatment method assessed in the present study. The proapoptotic effect of bufalin and hydroxycamptothecin may occur via signaling pathways associated with mitochondrial apoptosis, PI3K/AKT/GSK-3 $\beta$ apoptotic signaling and p53-dependent apoptosis regulation.

\section{Acknowledgements}

Not applicable.

\section{Funding}

The present study was funded by the Shanghai Putuo Hospital, Shanghai University of Traditional Chinese Medicine (grant no. 2016233A).

\section{Availability of data and materials}

The datasets used and/or analyzed during the current study are available from the corresponding author on reasonable request.

\section{Authors' contributions}

QZ performed the experimental work and collected and interpreted the data. RG designed the study, performed the analysis of the data, interpreted the data and drafted the manuscript. Both authors read and approved the final manuscript.

\section{Ethics approval and consent to participate}

The present study was approved by the Institutional Ethics Committee of Shanghai University of Traditional Chinese Medicine.

\section{Patient consent for publication}

Not applicable.

\section{Competing interests}

The authors declare that they have no competing interests.

\section{References}

1. Perez-Cornago A, Key TJ, Allen NE, Fensom GK, Bradbury KE, Martin RM and Travis RC: Prospective investigation of risk factors for prostate cancer in the UK Biobank cohort study. Br J Cancer 117: 1562-1571, 2017.

2. Ferlay J, Soerjomataram I, Dikshit R, Eser S, Mathers C, Rebelo M, Parkin DM, Forman D and Bray F: Cancer incidence and mortality worldwide: Sources, methods and major patterns in GLOBOCAN 2012. Int J Cancer 136: E359-E386, 2015.

3. Salinas CA, Tsodikov A, Ishak-Howard M and Cooney KA: Prostate cancer in young men: An important clinical entity. Nat Rev Urol 11: 317-323, 2014.

4. Chen W, Zheng R, Baade PD, Zhang S, Zeng H, Bray F, Jemal A, Yu XQ and He J: Cancer statistics in China, 2015. CA Cancer J Clin 66: 115-132, 2016.

5. Litwin MS and Tan HJ: The diagnosis and treatment of prostate cancer: A review. JAMA 317: 2532-2542, 2017.

6. Sountoulides P and Rountos T: Adverse effects of androgen deprivation therapy for prostate cancer: Prevention and management. ISRN Urol 2013: 240108, 2013.

7. Klarskov LL, Klarskov P, Mommsen S and Svolgaard N: Effect of endocrine treatment on voiding and prostate size in men with prostate cancer: A long-term prospective study. Scand J Urol Nephrol 46: 37-43, 2012.

8. Hotte SJ and Saad F: Current management of castrate-resistant prostate cancer. Curr Oncol 17 (Suppl 2): S72-S79, 2010.

9. Cheng CS, Wang J, Chen J, Kuo KT, Tang J, Gao H, Chen L, Chen Z and Meng Z: New therapeutic aspects of steroidal cardiac glycosides: The anticancer properties of Huachansu and its main active constituent Bufalin. Cancer Cell Int 19: 92, 2019.

10. Yin PH, Liu X, Qiu YY, Cai JF, Qin JM, Zhu HR and Li Q: Anti-tumor activity and apoptosis-regulation mechanisms of bufalin in various cancers: New hope for cancer patients. Asian Pac J Cancer Prev 13: 5339-5343, 2012.

11. Qiu DZ, Zhang ZJ, Wu WZ and Yang YK: Bufalin, a component in Chansu, inhibits proliferation and invasion of hepatocellular carcinoma cells. BMC Complement Altern Med 13: 185, 2013.

12. Chen Y, Guo Q, Zhang B, Kang M, Xie Q and Wu Y: Bufalin enhances the antitumor effect of gemcitabine in pancreatic cancer. Oncol Lett 4: 792-798, 2012.

13. Liu T and Huang Q: Biodegradable brush-type copolymer modified with targeting peptide as a nanoscopic platform for targeting drug delivery to treat castration-resistant prostate cancer. Int $\mathrm{J}$ Pharm 511: 1002-1011, 2016.

14. Yu CH, Kan SF, Pu HF, Jea Chien E and Wang PS: Apoptotic signaling in bufalin- and cinobufagin-treated androgen-dependent and -independent human prostate cancer cells. Cancer Sci 99: 2467-2476, 2008.

15. Pastor $\mathrm{N}$ and Cortés F: Bufalin influences the repair of X-ray-induced DNA breaks in Chinese hamster cells. DNA Repair (Amst) 2: 1353-1360, 2003.

16. Han KQ, Huang G, Gu W, Su YH, Huang XQ and Ling CQ: Anti-tumor activities and apoptosis-regulated mechanisms of bufalin on the orthotopic transplantation tumor model of human hepatocellular carcinoma in nude mice. World J Gastroenterol 13: 3374-3379, 2007.

17. Hashimoto S, Jing Y, Kawazoe N, Masuda Y, Nakajo S, Yoshida T, Kuroiwa Y and Nakaya K: Bufalin reduces the level of topoisomerase II in human leukemia cells and affects the cytotoxicity of anticancer drugs. Leuk Res 21: 875-883, 1997.

18. Chang Y, Zhao Y, Zhan H, Wei X, Liu T and Zheng B: Bufalin inhibits the differentiation and proliferation of human osteosarcoma cell line hMG63-derived cancer stem cells. Tumour Biol 35: 1075-1082, 2014.

19. Jiang Y, Zhang Y, Luan J, Duan H, Zhang F, Yagasaki K and Zhang G: Effects of bufalin on the proliferation of human lung cancer cells and its molecular mechanisms of action. Cytotechnology 62: 573-583, 2010.

20. Chueh FS, Chen YY, Huang AC, Ho HC, Liao CL, Yang JS, Kuo CL and Chung JG: Bufalin-inhibited migration and invasion in human osteosarcoma U-2 OS cells is carried out by suppression of the matrix metalloproteinase-2, ERK, and JNK signaling pathways. Environ Toxicol 29: 21-29, 2014.

21. Hong SH, Kim GY, Chang YC, Moon SK, Kim WJ and Choi YH: Bufalin prevents the migration and invasion of T24 bladder carcinoma cells through the inactivation of matrix metalloproteinases and modulation of tight junctions. Int $\mathrm{J}$ Oncol 42: 277-286, 2013. 
22. Cortés F and Piñero J: Synergistic effect of inhibitors of topoisomerase I and II on chromosome damage and cell killing in cultured Chinese hamster ovary cells. Cancer Chemother Pharmacol 34: 411-415, 1994.

23. Wethington SL, Wright JD and Herzog TJ: Key role of topoisomerase I inhibitors in the treatment of recurrent and refractory epithelial ovarian carcinoma. Expert Rev Anticancer Ther 8: 819-831, 2008

24. Lee YC, Lee CH, Tsai HP, An HW, Lee CM, Wu JC, Chen CS, Huang SH, Hwang J, Cheng KT, et al: Targeting of topoisomerase I for prognoses and therapeutics of camptothecin-resistant ovarian cancer. PloS One 10: e0132579, 2015.

25. Cuya SM, Bjornsti MA and van Waardenburg RCAM: DNA topoisomerase-targeting chemotherapeutics: What's new? Cancer Chemother Pharmacol 80: 1-14, 2017.

26. Deweese JE, Osheroff MA and Osheroff N: DNA topology and topoisomerases: Teaching a 'Knotty' subject. Biochem Mol Bio Educ 37: 2-10, 2008

27. Ding X, Matsuo K, Xu L, Yang J and Zheng L: Optimized combinations of bortezomib, camptothecin, and doxorubicin show increased efficacy and reduced toxicity in treating oral cancer. Anticancer Drugs 26: 547-554, 2015.

28. Cho YS and Cho-Chung YS: Antisense protein kinase A RIalpha acts synergistically with hydroxycamptothecin to inhibit growth and induce apoptosis in human cancer cells: Molecular basis for combinatorial therapy. Clin Cancer Res 9: 1171-1178, 2003.

29. Griffith TS and Kemp TJ: The topoisomerase I inhibitor topotecan increases the sensitivity of prostate tumor cells to TRAIL/Apo-2L-induced apoptosis. Cancer Chemother Pharmacol 52: 175-184, 2003.

30. Wei W, Yu Y, Wang X, Yang L, Zhang H, Ji H, Li Z, Hou J, Wu W and Guo D: Simultaneous determination of bufalin and its nine metabolites in rat plasma for characterization of metabolic profiles and pharmacokinetic study by LC-MS/MS Molecules 24: E1662, 2019.

31. Keshav R and Narayanappa U: Expression of proliferating cell nuclear antigen (PCNA) in oral submucous fibrosis: An immunohistochemical study. J Clin Diagn Res 9: ZC20-ZC23, 2015.

32. Liu X, Xiao XY, Shou QY, Yan JF, Chen L, Fu HY and Wang JC: Bufalin inhibits pancreatic cancer by inducing cell cycle arrest via the c-Myc/NF- $\kappa$ B pathway. J Ethnopharmacol 193: 538-545, 2016.

33. Li Y, Tian X, Liu X and Gong P: Bufalin inhibits human breast cancer tumorigenesis by inducing cell death through the ROS-mediated RIP1/RIP3/PARP-1 pathways. Carcinogenesis 39: 700-707, 2018

34. Li H, Hu S, Pang Y, Li M, Chen L, Liu F, Liu M, Wang Z and Cheng X: Bufalin inhibits glycolysis-induced cell growth and proliferation through the suppression of Integrin B2/FAK signaling pathway in ovarian cancer. Am J Cancer Res 8: 1288-1296, 2018

35. Pan Z, Xie Y, Bai J, Lin Q, Cui X and Zhang N: Bufalin suppresses colorectal cancer cell growth through promoting autophagy in vivo and in vitro. RSC Advances 8: 38910-38918, 2018.

36. Wang Y, Lonard DM, Yu Y, Chow DC, Palzkill TG, Wang J, Qi R, Matzuk AJ, Song X, Madoux F, et al: Bufalin is a potent small-molecule inhibitor of the steroid receptor coactivators SRC-3 and SRC-1. Cancer Res 74: 1506-1517, 2014.

37. Zhang ZJ, Yang YK and Wu WZ: Bufalin attenuates the stage and metastatic potential of hepatocellular carcinoma in nude mice. J Transl Med 12: 57, 2014.

38. Choo GS, Lee HN, Shin SA, Kim HJ and Jung JY: Anticancer effect of fucoidan on DU-145 prostate cancer cells through inhibition of PI3K/Akt and MAPK pathway expression. Mar Drugs 14: E126, 2016

39. Bertrand R, O'Connor PM, Kerrigan D and Pommier Y: Sequential administration of camptothecin and etoposide circumvents the antagonistic cytotoxicity of simultaneous drug administration in slowly growing human colon carcinoma HT-29 cells. Eur J Cancer 28A: 743-748, 1992.

40. Li M, Yu X, Guo H, Sun L, Wang A, Liu Q, Wang X and Li J: Bufalin exerts antitumor effects by inducing cell cycle arrest and triggering apoptosis in pancreatic cancer cells. Tumour Biol 35 2461-2471, 2014

41. Zhao H, Li Q, Pang J, Jin H, Li H and Yang X: Blocking autophagy enhances the pro-apoptotic effect of bufalin on human gastric cancer cells through endoplasmic reticulum stress. Biol Open 6: 1416-1422, 2017
42. Wu SH, Bau DT, Hsiao YT, Lu KW, Hsia TC, Lien JC, Ko YC, Hsu WH, Yang ST, Huang YP and Chung JG: Bufalin induces apoptosis in vitro and has Antitumor activity against human lung cancer xenografts in vivo. Environ Toxicol 32: 1305-1317, 2017.

43. Zhu Z, Sun H, Ma G, Wang Z, Li E, Liu Y and Liu Y: Bufalin induces lung cancer cell apoptosis via the inhibition of PI3K/Akt pathway. Int J Mol Sci 13: 2025-2035, 2012.

44. Miao Q, Bi LL, Li X, Miao S, Zhang J, Zhang S, Yang Q, Xie YH, Zhang J and Wang SW: Anticancer effects of bufalin on human hepatocellular carcinoma HepG2 cells: Roles of apoptosis and autophagy. Int J Mol Sci 14: 1370-1382, 2013.

45. Tu SP, Zhong J, Tan JH, Jiang XH, Qiao MM, Wu YX and Jiang SH: Induction of apoptosis by arsenic trioxide and hydroxycamptothecin in gastric cancer cells in vitro. World J Gastroenterol 6: 532-539, 2000.

46. Liu Y, Wang X, Jia Y and Liu Y: Effects of bufalin on the mTOR/p70S6K pathway and apoptosis in esophageal squamous cell carcinoma in nude mice. Int J Mol Med 40: 357-366, 2017.

47. Guo F, Fan Z, Yang J, Li Y, Wang Y, Zhao H, Xie L and Hou Z: A comparative evaluation of hydroxycamptothecin drug nanorods with and without methotrexate prodrug functionalization for drug delivery. Nanoscale Res Lett 11: 384, 2016.

48. Lee EF, Harris TJ, Tran S, Evangelista M, Arulananda S, John T, Ramnac C, Hobbs C, Zhu H, Gunasingh G, et al: BCL-XL and MCL-1 are the key BCL-2 family proteins in melanoma cell survival. Cell Death Dis 10: 342, 2019.

49. Hu X, Bardhan K, Paschall AV, Yang D, Waller JL, Park MA, Nayak-Kapoor A, Samuel TA, Abrams SI and Liu K: Deregulation of apoptotic factors Bcl-xL and Bax confers apoptotic resistance to myeloid-derived suppressor cells and contributes to their persistence in cancer. J Biol Chem 288: 19103-19115, 2013.

50. Szabó I, Bock J, Grassmé H, Soddemann M, Wilker B, Lang F, Zoratti $\mathrm{M}$ and Gulbins E: Mitochondrial potassium channel Kv1.3 mediates Bax-induced apoptosis in lymphocytes. Proc Natl Acad Sci USA 105: 14861-14866, 2008.

51. Wang C and Youle RJ: The role of mitochondria in apoptosis*. Annu Rev Genet 43: 95-118, 2009.

52. Er E, Oliver L, Cartron PF, Juin P, Manon S and Vallette FM: Mitochondria as the target of the pro-apoptotic protein Bax. Biochim Biophys Acta 1757: 1301-1311, 2006.

53. ZhangL,ChenD, Chen Zand MoeckelGW:Hypertonicity-induced mitochondrial membrane permeability in renal medullary interstitial cells: Protective role of osmolytes. Cell Physiol Biochem 25: 753-760, 2010

54. Voutsadakis IA: Apoptosis and the pathogenesis of lymphoma. Acta Oncol 39: 151-156, 2000.

55. Schon EA and Giovanni M: Neuronal degeneration and mitochondrial dysfunction. J Clin Invest 111: 303-312, 2003.

56. Horn HF and Vousden KH: Coping with stress: Multiple ways to activate p53. Oncogene 26: 1306-1316, 2007.

57. Lankat-Buttgereit B and Göke R: The tumour suppressor Pdcd4: Recent advances in the elucidation of function and regulation. Biol Cell 101: 309-317, 2009.

58. Brady CA and Attardi LD: p53 at a glance. J Cell Sci 123: 2527-2532, 2010

59. Holley AK and St Clair DK: Watching the watcher: Regulation of p53 by mitochondria. Future Oncol 5: 117-130, 2009.

60. Kuribayashi K, Krigsfeld G, Wang W, Xu J, Mayes PA, Dicker DT, Wu GS and El-Deiry WS: TNFSF10 (TRAIL), a p53 target gene that mediates p53-dependent cell death. Cancer Biol Ther 7: 2034-2038, 2008

61. Li X, Li Z, Qiu L, Zhao C and Hu Z: Nerve growth factor modulate proliferation of cultured rabbit corneal endothelial cells and epithelial cells. J Huazhong Univ Sci Technolog Med Sci 25: 575-577, 2005.

62. Bassili M, Birman E, Schor NF and Saragovi HU: Differential roles of Trk and 75 neurotrophin receptors in tumorigenesis and chemoresistance ex vivo and in vivo. Cancer Chemother Pharmacol 65: 1047-1056, 2010.

63. Chen S, Guttridge DC, You Z, Zhang Z, Fribley A, Mayo MW, Kitajewski J and Wang CY: Wnt-1 signaling inhibits apoptosis by activating beta-catenin/T cell factor-mediated transcription. J Cell Biol 152: 87-96, 2001.

This work is licensed under a Creative Commons

Attribution-NonCommercial-NoDerivatives 4.0 International (CC BY-NC-ND 4.0) License. 